\title{
Konflik batin dan perwatakan pada tokoh Ahmad Karaeng dalam novel "RINDU” karya Tere Liye: pendekatan psikologi
}

\author{
Rizky Ade Prayoga ${ }^{1}$, Aris Wuryantoro ${ }^{2}$ \\ 1,2) Universitas PGRI Madiun, JI. Setibudi No. 85 Madiun, Indonesia \\ e-mail: ${ }^{1)}$ r.adeprayoga@gmail.com; ${ }^{2)}$ allam_71@yahoo.co.id
}

\begin{abstract}
Abstrak
Tujuan penelitian ini adalah (1) mendeskripsikan konflik batin dan perwatakan tokoh Ahmad Karaeng dalam novel Rindu karya Tere Liye dan (2) mendeskripsikan perwatakan tokoh Ahmad Karaeng dalam novel Rindu karya Tere Liye dengan pendekatan psikologi sastra. Rancangan penelitian yang dipergunakan adalah penelitian dengan metode deskriptif kualitatif untuk memberikan gambaran yang secermat mungkin mengenai konflik batin dan perwatakan tokoh Ahmad Karaeng dalam novel "Rindu" karya Tere Liye. Penelitian ini adalah penelitian pustaka dengan subjek penelitian novel "Rindu" karya Tere Liye yang diterbitkan oleh Republika Penerbit tahun 2014. Objek penelitian ini adalah mengenai perwatakan tokoh utama, yaitu Ahmad Karaeng pada "Rindu" karya Tere Liye. Teknik pengumpulan data yang digunakan dalam penelitian ini adalah dengan menggunakan teknik baca dan catat. Teknik analisis data yang digunakan dalam penelitian ini adalah teknik deskriptif. Hasil penelitian: (1) perwatakan tokoh Ahmad Karaeng dalam novel Rindu karya Tere Liye meliputi: menerima takdir, pribadi yang selalu bersyukur, menaati perintah Allah, SWT., tobat, tawakal, adil terhadap diri sendiri, (g) gigih, (h) tidak mementingkan diri sendiri, sabar, ikhlas, tegar, optimis, lapang dada, ta'awun (selalu menolong orang lain), berkumpul dengan orang baik, memiliki solidaritas, menghargai orang lain, dan pemaaf. (2) Konflik batin pada tokoh Ahmad Karaeng dalam novel Rindu karya Tere Liye merupakan konflik internal, yaitu adanya perasaan pada Ahmad Karaeng bahwa dirinya adalah seorang yang munafik, ia dapat bersikap bijak di depan siapa pun namun hati dan pikirannya selalu menanyakan apakah ia setangguh kata-kata yang diucapkannya. la menyimpan perasaan bersalah dan mengaggap dirinya sebagai pengecut. Ahmad Karaeng sangat terpukul dengan masa lalu yang telah ia lewati. la sangat sedih telah kehilangan orang-orang yang sangat dicintai dan dihormatinya. Penyesalan terbesar Ahmad Karaeng pada kejadian itu adalah tidak dapat menyelamatkan orang-orang yang dekat padanya. Penyesalan itu sampai sekarang ia alami.
\end{abstract}

Kata kunci: Konflik Batin, Perwatakan; Novel; Psikologi Sastra

\section{Inner conflicts and characterization of main character Ahmad Karaeng in Tere Liye's novel "Rindu": a psychological approach}

\begin{abstract}
The objectives of this research are (1) to describe the inner conflict and character of Ahmad Karaeng in Tere Liye's Rindu novel and (2) to describe the character of Ahmad Karaeng in Tere Liye's Rindu novel viewed from a psychological approach. The research design used was descriptive qualitative method to give as accurate description as possible about the inner conflicts and character of Ahmad Karaeng in Tere Liye's novel "Rindu". This research subject was novel "Rindu" by Tere Liye published by Republika in 2014. The object of this research was the main character
\end{abstract}


figure, Ahmad Karaeng in novel "Rindu" by Tere Liye. Data collection techniques was reading and taking notes. Data analysis technique used was descriptive technique. The findings are that: (1) the character of Ahmad Karaeng in Tere Liye's Rindu novel includes: accepting destiny, the person who is always grateful, obeys God's commands, belief, fair, persistent, selfless, patient, sincere, rigid, optimistic, ta'awun (always helping others), getting together with good people, having solidarity, respecting others, and forgiving. (2) The inner conflict of the Ahmad Karaeng character in Tere Liye's Rindu novel is an internal conflict, namely the feeling of Ahmad Karaeng that he is a hypocrite, he can be wise in front of other people but his heart and mind always wonders whether he is as tough as a word-the words he says. He keeps a guilty plea and regards himself as a coward. Ahmad Karaeng was devastated by the past. $\mathrm{He}$ is very sad to miss his beloved and respected people. Ahmad Karaeng's greatest regret at the incident is not able to save the people in his surrounding. He keeps regretting until today.

Keywords: Inner Conflict; Character; Novel; Litercay Psychology

\section{Pendahuluan}

Karya sastra merupakan pengungkapan kehidupan nyata menjadi sebuah karya imajinatif yang indah untuk dinikmati. Kehidupan dan realitas yang ada dalam karya sastra memiliki cakupan hubungan antara manusia dengan keadaan sosial yang menjadi inspirasi penciptaan. Dengan demikian dalam karya sastra tidak hanya sebuah imajinasi yang dapat dinikmati, tetapi juga dapat dipelajari mengenai sosiologi, psikologi, adat istiadat, moral, budi pekerti, agama, tuntunan masyarakat, dan tingkah laku manusia di suatu masa. Banyak hal yang dapat diambil dan dijadikan pelajaran yang berharga bagi penikmat karya sastra dari sebuah karya sastra.

Karya sastra pada dasarnya berupa karangan yang bersifat rekaan. Menurut Rene Wellek (dalam Pradopo, 2007: 35) bahwa karya sastra adalah karangan yang bersifat rekaan (fiction) berdasarkan daya angan (invention). Sebuah karya sastra meskipun gagasan atau inspirasinya diambil dari kehidupan yang nyata, tetapi sudah diolah oleh pengarangnya melalui imajinasinya atau daya angannya, dengan demikian tidak diharapkan realitas karya sastra sama dengan realitas kehidupan nyata. Pengarang sudah menambahkan angan-angannya dalam karyanya.

Sebuah karya sastra memiliki daya gugah terhadap batin dan jiwa seseorang. Selain itu, karya sastra juga merupakan media untuk mengutarakan sisi-sisi kehidupan manusia dan memuat kebenaran-kebenaran kehidupan manusia yang kadang-kadang kebenaran itu bersifat sejarah. Dalam bentuk genre, di antara genre besar karya sastra Indonesia yaitu novel, puisi dan drama. Novel adalah karangan prosa yang panjang mengandung rangkaian cerita kehidupan seseorang dengan orang di sekelilingnya dengan menonjolkan watak dan sifat setiap pelaku. Novel yang menceritakan tentang kehidupan tokoh-tokoh serta tingkah laku mereka dalam kehidupan sehari-hari. Tokohtokoh yang terdapat di dalam novel memiliki karakter yang berbeda-beda. Penokohan di dalam novel cukup menarik untuk dikaji lebih lanjut. Penokohan dikaji untuk mengetahui bagaimana perwatakan dari setiap tokoh yang ada di dalam sebuah novel. Salah satu penulis novel yang terkenal milik Indonesia adalah Tere Liye, karyanya begitu digemari oleh penghobi membaca dan selalu ditungu-tunggu karya-karya selanjutnya.

Novel Rindu karya Tere Liye memiliki kelebihan yang terletak pada tema yang tergolong unik dan baru, yakni masalah konflik batin yang dihubungakan dengan dunia 
kerinduan yang tersusun rapi dalam hatinya. Novel pada umumnya menceritakan kisah cinta terhadap lawan jenis, namun melalui novel ini kita menyadari bahwa cinta itu luas. Cinta terhadap diri sendiri, orang tua, teman, dan sahabat. Cinta yang dipaparkan oleh pengarang pun disertai dengan adanya rindu. Rindu ini menjadi salah satu konflik batin yang menarik. Selain itu, pengarang menambahkan unsur religius yang mendalam serta perjuangan ke Tanah Suci. Pengarang pun mampu memaparkan dengan detail kotakota besar di Indonesia yang dijadikan dermaga kapal yang ditumpanginya. Cerita pada novel ini tidak lepas dari perjalanan haji, namun pengarang mampu menyelipkan kejadian yang berpendidikan.

Tokoh Ahmad Karaeng berfungsi sebagai penggerak alur cerita secara aktif, karena tokoh ini merupakan salah satu unsur yang erat jalinannya dengan sudut pandang. Terdapat pesan yang besar dalam alur cerita dalam novel yang tersusun rapi menyerupai sajak-sajak yang dapat menyugesti pembaca. Diharapkan penelitian ini dapat memperkaya pemahaman tentang ragam karya sastra novel dengan cara memahami atau menganalisis konflik batin dan perwatakan tokoh utama khususnya dengan kajian psikologi sastra.

Menurut Sigmund Freud semua gejala yang bersifat mental bersifat tak sadar yang tertutup oleh alam kesadaran. Berdasarkan pemikiran tersebut, peneliti tertarik untuk mengkaji novel Rindu dari segi konflik batin dan perwatakan psikologi tokohnya, maka dari itu penelitian ini merupakan penelitian psikologi sastra yang menitikberatkan pada psikotekstual dengan menganalisis konflik batin dan perwatakan para tokoh dalam novel Rindu karya Tere Liye dengan berpedoman pada teori psikologi yang dikemukakan oleh Sigmund Freud.

Karakter Ahmad Karaeng adalah karakter yang sangat baik dan dapat diwujudkan dalam kehidupan nyata. Dan lebih lagi bagi para siswa pendidikan karakter sangat penting bagi perkembangan diri mereka, untuk membentuk jati diri yang lebih baik dari sebelumnya. Karena masa itu adalah masa dimana mereka masih belum memiliki jati diri dan sangat mudah dipengaruhi. Siswa membutuhkan bimbingan agar tidak salah mengambil keputusan untuk ke depannya.

Penelitian ini bertujuan untuk memberikan arah yang jelas pada penelitian yang dilakukan. Adapun tujuan yang hendak dicapai dalam penelitian ini adalah sebagai berikut: (1) Mendeskripsikan konflik batin dan perwatakan tokoh Ahmad Karaeng dalam novel Rindu karya Tere Liye dan (2) Mendeskripsikan perwatakan tokoh Ahmad Karaeng dalam novel Rindu karya Tere Liye dilakukan dengan pendekatan psikologi sastra.

Konflik merupakan bagian yang terpenting dalam sebuah cerita. Pentingnya kehadiran konflik dalam suatu cerita dijelaskan oleh Stanton (2012: 31) bahwa dua elemen dasar yang membangun alur adalah konflik dan klimaks. Setiap karya fiksi setidaknya-tidaknya memiliki konflik internal (yang tampak jelas) yang hadir melalui hasrat dua orang karakter atau hasrat seseorang karakter dengan lingkungannya. Konflik-konflik spesifik ini ini merupakan subordinasi satu konflik utama yang bersifat eksternal, internal, atau dua-duanya. Berdasarkan uraian di atas, dapat disampaikan bahwa pentingnya menghadirkan konflik dalam suatu cerita memang tidak dapat disangkali. Hal tersebut dikarenakan tanpa adanya konflik dalam sebuah alur, maka isi cerita dalam karya fiksi tersebut tidak akan menarik karena tak adanya proses klimaks yang menurut Tarigan (2008: 128) merupakan puncak tertinggi dalam serangkaian puncak tempat kekuatan-kekuatan dalam konflik mencapai intensifikasi yang tertinggi. 
Konflik dalam cerita menurut Sayuti (2010: 42-43) dapat dibedakan menjadi tiga jenis. (1) Konflik dalam diri seseorang (tokoh). Konflik jenis ini sering disebut psychological conflict 'konflik kejiwaan', yang biasanya berupa perjuangan seorang tokoh dalam melwan dirinya sendiri, sehingga dapat mengatasi dan menentukan apa yang akan dilakukannya, (2) Konflik antara orang-orang atau seseorang dan masyarakat. Konflik jenis ini sering disebut dengan social conflict 'konflik sosial', yang biasanya berupa konflik tokoh, dalam kaitannya dengan permasalahan-permasalahan sosial, (3) Konflik antara manusia dan alam. Konflik jenis ini sering disebut sebagai physical or element conflict 'konflik alamiah', yang biasanya muncul tatkala tokoh tidak dapat menguasai atau memanfaatkan serta membudayakan alam sekitar sebagaimana mestinya. Pada sebuah cerita biasanya antara pengarang satu dengan lainnya memiliki cara yang berbeda untuk mengakhiri kisah cerita. Wiyatmi (2011: 27) menjelaskan bahwa pada akhir cerita dikenal adanya plot terbuka dan plot tertutup. Plot disebut tertutup apabila sebuah cerita memiliki akhir (penyelesaian) yang jelas atau tidak menggantung, sedangkan pengertian plot terbuka merupakan oposisi dari plot tertutup.

Jadi, pada sebuah cerita biasanya antara pengarang satu dengan lainnya memiliki cara yang berbeda untuk mengakhiri kisah cerita tersebut. Dengan demikian, akhir dari sebuah cerita dikenal adanya istilah plot terbuka dan tertutup, di mana pengertian plot terbuka yaitu cerita tersebut pada akhirnya memiliki akhir cerita yang jelas dan bisa membuat pembaca paham dengan akhir cerita yang dialami oleh tokohtokoh di dalamnya sehingga tidak menimbulkan pertanyaan-pertanyaan dari pembaca tentang isi cerita tersebut. Sebaliknya, plot tertutup dapat diartikan dengan penyelesaian yang tidak jelas atau menggantung, biasanya hal tersebut dapat memberikan dua kesan pada para pembaca yaitu kesan kecewa karena isi cerita tidak berujung pada penyelesaian dan adanya pertanyaan yang timbul dari pembaca tentang maksud tersembunyi atau arti yang disampaikan oleh pengarang, sehingga pembaca harus menemukan maksud tersebut dari dugaan-dugaan yang ada dalam diri pembaca itu sendiri.

Karya sastra, baik puisi, novel, dan drama di zaman modern ini sarat dengan unsur-unsur psikologis sebagai manifestasi kejiwaan pengarang, para tokoh fiksional dalam kisahan dan pembaca (Minderop, 2013: 53). Walaupun sebenarnya karya sastra lama juga ada juga yang mengandung unsur-unsur psikologis, hal itu karena karya sastra adalah ciptaan manusia yang selalu berkaitan dengan spiritual dan emosional dalam diri manusia (pengarang). Salah satu pendekatan untuk menganalisis karya sastra yang sarat akan aspek-aspek kejiwaan adalah melalui pendekatan psikologi sastra. Psikologi sastra sebagai suatu pendekatan merupakan bentuk kreativitas yang dihadirkan melalui model penelitian interdisiplin dengan menetapkan karya sastra sebagai pemilik posisi yang lebih dominan (Ratna, 2011:349). Dari hal tersebut dapat diketahui bahwa psikologi sastra tak hanya menyodorkan model penelitian saja melainkan diikutsertakannya bentuk kreativitas ke dalam pendekatannya melalui teks.

Psikologi sastra adalah kajian sastra yang memandang karya sebagai aktivitasnya kejiwaan. Pengarang akan menggunakan cipta, rasa, dan karya dalam berkarya. Begitu pula pembaca, dalam menanggapi karya juga tak akan lepas dari kejiwaan masing-masing. Wiyatmi (2011: 1) menjelaskan bahwa psikologi sastra lahir sebagai salah satu jenis kajian sastra yang digunakan untuk membaca dan 
menginterpretasikan karya sastra, pengarang karya sastra dan pembacanya dengan menggunakan berbagai konsep dan kerangka teori yang ada dalam psikologi.

Pada dasarnya antara psikologi dan sastra memiliki persamaan, yaitu samasama membicarakan manusia dan keberlangsungannya sebagai makhluk individu dan makhluk sosial. Selain itu, keduanya juga memanfaatkan landasan yang sama yaitu menjadikan pengalaman manusia sebagai bahan telaah (Endraswara dalam Minderop, 2013: 2). Perbedaan diantara keduanya hanya terletak pada objek yang dibahas saja.Jika psikologi membicarakan manusia sebagai sosok yang riil sebagai ciptaan Tuhan, dalam karya sastra objek yang dibahas adalah tokoh-tokoh yang diciptakan oleh seorang pengarang atau disebut sebagai tokoh imajinasi semata.

Psikologi menurut Gerungan (dalam Walgito, 2010: 7-8) terdiri dari dua kata yakni psyche dan logos. Psyche merupakan bahasa Yunani yang memiliki arti jiwa dan kata logos yang berarti ilmu, sehingga ilmu jiwa merupakan istilah dari psikologi. Walaupun demikian pengertian antara psikologi dan ilmu jiwa memiliki perbedaan yang pada intinya sesuatu hal yang disebut dengan ilmu jiwa itu belum tentu bisa dikatakan sebagai psikologi, tetapi psikologi dapat diartikan sebagai ilmu jiwa. Psikologi merupakan ilmu yang dapat dihubungkan dengan karya sastra karena psikologi itu sendiri mengarah kepada suatu ilmu yang menyelidiki serta mempelajari tentang tingkah laku serta aktivitas-aktivitas di mana tingkah laku serta aktivitas-aktivitas itu sebagai manifestasi hidup kejiwaan (Walgito, 2010: 3).

Berdasarkan uraian pendapat di atas, psikologi merupakan salah satu ilmu yang memiliki kesan meluas. Kesan meluas tersebut dapat dilihat dari adanya hubungan antara ilmu psikologi dengan ilmu-ilmu yang lain seperti biologi, sosiologi, filsafat, ilmu pengetahuan alam, dan salah satunya yaitu hubungan antara psikologi dengan sastra.

Salah satu bentuk karya seni yang diciptakan oleh pengarang adalah cerita fiksi. Cerita fiksi seperti yang telah dijelaskan merupakan cerita rekaan yang dituliskan oleh seorang pengarang secara bebas melalui luapan emosi yang spontan, sehingga pengarang memiliki banyak kesempatan dalam menggambarkan secara keseluruhan unsur-unsur yang membangun cerita tersebut. Salah satu bentuk kebebasan yang dimiliki oleh seorang pengarang adalah pengarang bebas menentukan siapa sajakah tokoh yang akan hadir dalam karyanya beserta segala hal yang melekat pada diri tokohtokoh tersebut, seperti penokohan dan perwatakannya. Dengan demikian tokoh-tokoh fiksi memiliki kesan nyata sebagai manusia pada umumnya.

Sebagai tokoh imajinasi atau tokoh yang diciptakan oleh seorang pengarang bukanlah menjadi suatu pembatasan dengan tokoh nyata dalam menjalani proses kehidupan. Walaupun memiliki kesan imajiner, tokoh dalam fiksi juga memiliki peran yang sama dengan kehidupan manusia yang sebenarnya. Hal tersebut dikarenakan pengarang memasukkan aspek-aspek kemanusiaan pada diri tokoh-tokoh imajinasinya sehingga terkesan hidup selayaknya manusia pada umumnya dengan segala bentuk permasalahan yang dihadapi. Aspek-aspek kemanusiaan itulah yang nantinya merupakan objek utama psikologi sastra.

Keberadaan sastra jika digunakan dalam kerangka ilmu sastra mengacu pada salah satu cabang ilmu pengetahuan yang mengkaji karya sastra sebagai objek formalnya secara bersistem dan terorganisir. Melalui kajian sastra yang menggunakan pendekatan psikologi sastra inilah hubungan antara sastra dan psikologi terjadi. 
Secara definitif, tujuan psikologi sastra adalah memahami aspek-aspek kejiwaan yang terkandung dalam suatu karya sastra. Meskipun demikian, bukan berarti bahwa analisis psikologi sastra sama sekali terlepas dengan kebutuhan masyarakat. Sesuai dengan hakikatnya, karya sastra memberikan pemahaman terhadap secara tidak langsung. Melalui pemahaman terhadap tokoh-tokohnya, misal, masyarakat dapat memahami perubahan, kontradiksi, dan penyimpangan-penyimpangan lain yang terjadi dalam masyarakat, khususnya kaitannya dengan psike (Ratna, 2011:342).

Jadi, dalam hal mengkaji sebuah karya sastra, pendekatan psikologi sastra sangatlah membantu. Psikologi diperlukan dalam karya sastra guna mengkaji karakter tokoh-tokoh dan segala hal yang berkaitan dengan proses psikologi yang dihadirkan oleh seorang pengarang. Pentingnya konsep tidak lain dilatarbelakangi adanya harapan hubungan diantara psikologi dan sastra yang kemudian dikenal sebagai psikologi sastra mampu untuk menemukan aspek-aspek ketaksadaran yang menyebabkan terjadinya gangguan psikologi pada diri tokoh-tokoh dalam cerita.

\section{Metode Penelitian}

Jenis penelitian ini adalah penelitian deskritif kualitatif. Metode deskriptif kualitatif digunakan untuk mendeskripsikan perwatakan tokoh utama dan konflik batin yang dialami tokoh utama. Sutopo (2002: 111) menyebutkan bahwa penelitian deskriptif kualitatif mengarah pada pendeskripsian secara rinci dan mendalam mengenai potret kondisi tentang apa yang sebenarnya terjadi menurut apa adanya di lapangan studinya. Sedangkan Bogdan dan Taylor (dalam Moleong, 2010: 4) mendefinisikan pendekatan kualitatif sebagai prosedur penelitian yang menghasilkan data deskriptif berupa katakata tertulis atau lisan dari orang-orang dan perilaku yang dapat diamati. Berdasarkan pendapat-pendapat di atas, penelitian deskriptif kualitatif mengarah pada pendeskripsian secara rinci dan mendalam mengenai permasalahan yang ada di lapangan.

Pada suatu penelitian, data merupakan bahan utama dari pengkajian atas masalah yang diteliti. Sudaryanto (dalam Kesuma, 2007: 25) menyebutkan bahwa data merupakan bahan jadi penelitian. Penelitian ini adalah penelitian pustaka dengan subjek penelitian novel "Rindu" karya Tere Liye yang diterbitkan oleh Penerbit Republika tahun 2014. Objek penelitian ini adalah mengenai perwatakan tokoh utama, yaitu Ahmad Karaeng pada "Rindu" karya Tere Liye.

Teknik pengumpulan data dalam penelitian ini berupa teknik pustaka. Subroto (dalam Kartika, 2008:18) berpendapat bahwa teknik pustaka adalah teknik yang menggunakan sumber-sumber tertulis untuk memperoleh data. Penelitian ini menggunakan buku-buku sebagai sumber pustaka dan kutipan percakapan dalam Novel "Rindu" karya Tere Liye sebagai objek penelitian untuk dianalisis aspek-aspek psikoanalisis yang ada di dalamnya. Teknik pengumpulan data yang digunakan dalam penelitian ini adalah dengan menggunakan teknik baca dan catat, Kegiatan pembaca dilakukan dengan cermat secara berulang-ulang agar data yang diperoleh benar-benar yang berhubungan dengan fokus penelitian yaitu tentang analisis karakter tokoh Ahmad Karaeng dalam novel Rindu.

Triangulasi yang sesuai untuk menguji keabsahan data penelitian ini adalah triangulasi sumber. Triangulasi sumber dilakukan untuk menguji kredibilitas data, dilakukan dengan cara mengecek data yang telah diperoleh melalui beberapa sumber 
(Sugiyono, 2014: 274). Triangulasi sumber dipilih mengingat karakteristik data penelitian, yaitu tentang analisis perwatakan dan konflik batin tokoh Ahmad Karaeng dalam novel Rindu karya Tere Liye bersumber dari kutipan-kutipan dari dalam novel. Perlu digunakan beberapa perspektif sumber dari dalam novel dan teori Psikoanalisis Sigmund Freud untuk membahas permasalahan yang dikaji agar dapat ditarik simpulan yang bisa diterima kebenarannya.

Teknik analisis data yang digunakan dalam penelitian ini adalah teknik deskriptif. Penggunaan teknik deskriptif dilakukan mengingat data-data verbal dalam penelitian ini berupa analisis konflik batin dan perwatakan tokoh Ahmad Karaeng berdasarkan teori Psikoanalisis Sigmund Freud yang bersifat verbal sehingga penjelasannya berupa suatu deskripsi. Analisis data dalam penelitian ini akan membahas analisis konflik batin dan perwatakan pada tokoh Ahmad Karaeng dalam novel "Rindu" karya Tere Liye menggunakan pendekatan Psikologi Sastra.

\section{Hasil dan Pembahasan}

Tere Liye lahir dan tumbuh dewasa di pedalaman Sumatera pada tanggal $21 \mathrm{Mei}$ 1979. Tere Liye menikah dengan Ny.Riski Amelia dan dikarunia seorang putra bernama Abdullah Pasai. Tere Liye tumbuh di Sumatera Pedalaman. la berasal dari keluarga sederhana yang orang tuanya berprofesi sebagai petani biasa. Anak ke-enam dari tujuh bersaudara ini sampai saat ini telah menghasilkan 14 karya. Bahkan beberapa di antaranya telah di angkat ke layar lebar. Tere Liye meyelesaikan masa pendidikan dasar sampai SMP di SDN 2 dan SMN 2 Kikim Timur, Sumatera Selatan. Kemudian melanjutkan ke SMUN 9 Bandar Lampung. Setelah selesai di Bandar Lampung, ia meneruskan ke Universitas Indonesia dengan mengambil Fakultas Ekonomi. Berikut beberapa karya-karya Tere Liye: (a) Daun Yang Jatuh Tak Pernah Membenci Angin (Gramedia Pustaka Umum, 2010), (b) Pukat (Penerbit Republika, 2010), (c) Burlian (Penerbit Republika, 2009), (d) Hafalan Shalat Delisa (Penerbit Republika, 2005), (e) Moga Bunda Disayang Alloh (Penerbit Republika, 2005), (f) Bidadari-Bidadari Surga (Penerbit Republika, 2008), (g) Senja Bersama Rosie (Penerbit Grafindo, 2008), dan (h) Eliana, Serial Anak-Anak Mamak (Penerbit Republika, 2009).

"Rindu" adalah novel persembahan Tere Liye di tahun 2014 yang betul-betul dirindukan. "Rindu" merupakan buku ke-20 karya Tere Liye. Semua karya-karyanya memiliki ciri khas dan cita rasa yang berbeda. "Rindu" adalah karya yang tak pernah terbayangkan karena Tere Liye menyuguhkan tema yang tidak biasa. ide penulisan novel "Rindu" belum pernah ada di dunia perbukuan Indonesia. Sederhana, tidak mulukmuluk, tapi segar. Novel ini tentang perjalanan panjang jamaah haji Indonesia tahun 1938, tentang kapal uap Blitar Holland, tentang sejarah nusantara, dan tentang pertanyaan-pertanyaan seputar masa lalu, kebencian, takdir, cinta, dan kemunafikan. Ditulis dengan alur maju, memudahkan pembaca mengikuti jalan cerita. Namun di beberapa bagian, penulis menyuguhkan cerita-cerita lain dalam bentuk dialog, yang berkorelasi pada kisah yang tengah disajikan.Membuat pembaca mengenal secara utuh racikan cerita di novel ini, sehingga setting novel yang didominasi aktifitas penumpang di kapal Blitar Holland, tidak terasa membosankan.

Gaya kepenulisan novel "Rindu" terbilang sederhana. Membumi, disisipi dialog bahasa Belanda, yang meski tidak disertakan artinya, pembaca terbantu memahami maksud kalimat dengan deskripsi yang ditulis Tere Liye. 
“Mag ik uw kaatje, Meneer?"Salah satu kelasi bertanya sopan, persis saat Gurutta menginjak dek kapal, menanyakan tiket dan dokumen perjalanan (Liye, 2015: 35).

Novel ini dibuka dengan mukadimah yang unik. Tere Liye menukil fakta sejarah nusantara di tahun 1938. Salah satunya, Indonesia (yang masih bernama Hindia Belanda) mengikuti Piala Dunia di Prancis untuk pertama kalinya. Seterusnya, sosok kapal uap yang akan menjadi saksi seluruh cerita di novel setebal 544 ini mulai digambarkan penulis. Untuk kemudian, Tere Liye menghadirkan satu persatu tokohtokoh dalam novel ini. Sebuah perjalanan panjang ini dimulai ketika sebuah kapal besar bernama Blitar Holland mendarat di Pelabuhan Makassar. Kapal tersebut nantinya akan berhenti dan menaikkan penumpang di pelabuhan Surabaya, Semarang, Batavia, Lampung, Bengkulu, Padang, Banda Aceh. Kapal itu akan terus melaju hingga Jeddah karena para penumpang kapal tersebut adalah calon jamaah haji. Satu persatu, tokoh dalam novel ini diperkenalkan.Tersebutlah Daeng Andipati, seorang yang terpandang karena telah berhasil menyelesaikan sekolahnya di Belanda. la bersama istri dan kedua anaknya, Elsa dan Ana. Gurruta atau Ahmad Karaeng pun menjadi tokoh penting dalam novel ini.la adalah seorang ulama masyhur. Adapula Kapten Philips, kapten kapal yang akan membawa penumpang menunaikan ibadah haji di Mekah. Serta ada Ambo Uleng, seorang kelasi pendiam yang direkrut oleh Kapten Philips dan menjadi satu-satunya kelasi yang dapat berbahasa Melayu.

Hal baru dari novel "Rindu" ini adalah kemunculan tokoh ulama. Ini istimewa, karena di novel yang lain, Tere Liye belum pernah mengambil karakter seorang ulama, yang ada dibenak pembaca bila disebut kata ulama, tentu terbayang sosok manusia dengan seluruh kesempurnaan ilmu dan adab. Begitu juga dengan Ahmad Karaeng, seseorang yang dipanggil Gurutta itu digambarkan sebagai ulama yang sempurna. Berilmu, Beradab, Bahkan empat dari lima pertanyaan besar di novel "Rindu" terjawab sempurna dari lisannya yang bijak. Namun Gurutta bukan ulama biasa. la ulama bersahaja, yang rendah hati, dicintai banyak orang karena tinggi budinya. Sikapnya terbuka pada siapapun. Mau membaur dengan orang-orang yang jauh kapasitas keilmuannya. Bahkan Gurutta akrab dengan orang-orang Belanda di kapal Blitar Holland, duduk satu meja dengan Chef Lars, berbincang santai dengan Ruben si Boatswain, dan melibatkan diri pada urusan-urusan penting selama di kapal bersama Kapten Phillips.

Ada banyak hal menarik pada sosok Ahmad Karaeng. Namun di luar semua kelebihannya, Ahmad Karaeng tetaplah manusia biasa. Dia bahkan menyembunyikan sesuatu. Sesuatu yang begitu dia khawatirkan.Sesuatu yang mengganggu batinnya. Lihatlah kemari wahai gelap malam. Lihatlah seorang yang selalu pandai menjawab pertanyaan orang lain, tapi dia tidak pernah bisa menjawab pertanyaannya sendiri. Lihatlah ke mari wahai lautan luas. Lihatlah seorang yang selalu punya kata bijak untuk orang lain, tapi dia tidak pernah bisa bijak untuk dirinya sendiri. (Liye, 2015: 316)

Seperti biasa, tema cinta tidak akan pernah lepas dari novel dengan genre apapun. Dalam novel "Rindu", Tere Liye juga menghadirkan tokoh yang berhasil membuat pembaca jatuh cinta, sepasang pasutri sepuh dari Semarang. Mbah Kakung dan Mbah Putri Slamet. Diantara ribuan penumpang kapal Blitar Holland, merekalah pasangan paling sepuh sekaligus paling romantis.

Pendengaranku memang sudah tidak bagus lagi, Nak. Juga mataku sudah rabun.Tubuh tua ini juga sudah bungkuk. Harus kuakui itu. Tapi aku masih ingat kapan 
aku bertemu istriku. Kapan aku melamarnya. Kapan kami menikah. Tanggal lahir semua anak-anak kami.Waktu-waktu indah milik kami.Aku ingat itu semua" (Liye, 2015: 205) Tere Liye seakan berpesan kepada pembaca, terutama kawula muda, bahwa contoh konkret cinta sejati adalah pasangan yang sudah berpuluh tahun mengarungi bahtera rumah tangga. Bukan kawula muda yang bergaul bebas, tanpa komitmen, dan melanggar begitu banyak rambu-rambu agama atas nama cinta. Sayangnya, ada hal yang membuat dada sesak dalam perjalanan cinta mereka. Sesuatu yang kemudian menjadi salah satu pertanyaan besar dalam novel ini.

Tema cinta juga datang dari tokoh pemuda bernama Ambo Uleng. Si kelasi pendiam yang suka berdiam diri menatap jendela bundar di kabin. Meski Tere Liye baru membeberkan dibalik kemisteriusan Ambo Uleng di halaman 483, sebenarnya pembaca sudah bisa menebak apa yang sesungguhnya terjadi dengaan pemuda itu. "Aku hanya ingin meninggalkan semuanya, Kapten" (Liye, 2015: 33). Banyak sifat baik Ambo Uleng yang bisa dijadikan teladan. Keinginannya belajar mengaji salah satunya, tidak masalah meski harus belajar dengan Anna, si gadis kecil yang pernah ia tolong dalam sebuah peristiwa besar di Surabaya. Kecerdasan dan kecakapan Ambo Uleng menyertai beberapa adegan heroik di novel ini. Namun yang paling berkesan, lima dari empat pertanyaan besar di novel ini, yang datang dari seseorang yang selalu memberikan jawaban, justru lahir dari sosok Ambo Uleng. Pertanyaan yang bukan dari penjelasan lisan atau tulisan, tapi dengan perbuatan tangan (Liye, 2015: 540).

Tokoh terakhir dari tokoh-tokoh sentral dalam novel "Rindu" adalah Bonda Upe. Guru mengaji anak-anak di kapal Blitar Holland ini membuat saya jatuh simpati. Tere Liye menggambarkan suasana batin Bonda Upe dengan sempurna. Siapapun yang membaca, seolah dapat merasakan sesuatu yang terpendam di dada perempuan itu. Sesak, gelisah, pun saat-saat ia menemukan secercah cahaya yang membuatnya bisa memandang hidupnya dengan perasaan lapang. Menariknya, Bonda Upe adalah warga keturunan China dan Muslim.Sesuatu yang mungkin masih menjadi hal yang asing pada saat itu.

"Ma, kalau Bonda Upe itu orang China, kenapa dia Islam?"

"Koh Acan di Kampung Butung juga Islam, apanya yang aneh?" (Liye, 2015: 108).

Dalam perjalanannya ke Tanah Suci, Bonda Upe membawa pertanyaan besar. Berkitan dengan masa lalunya sebagai cabo. Ada pelajaraan penting yang bisa diambil dari kehidupan Bonda Upe.Salah satunya adalah nilai ketulusan seorang Enlai, suami Bonda Upe.

"Dia tulus menyemangatimu, tulus mencintaimu. Padahal, dia tahu persis kau seorang cabo. Sedikit sekali laki-laki yang bisa menyayangi seorang cabo. Tapi Enlai bisa, karena dia menerima kenyataan itu. Dia peluk erat sekali. Dia bahkan tidak menyerah meski kau telah menyerah. Dia bahkan tidak berhenti meski kau telah berhenti (Liye, 2015: 312).

Bukan hanya berisi tokoh-tokoh yang menarik novel "Rindu", meski hanyalah potret perjalanan ke Tanah Suci di atas kapal uap milik Belanda, novel ini juga menyajikan beragam konflik yang tidak pernah terduga. Diantaranya tragedi penyerangan kapal oleh bajak laut dari Somalia, kapal yang terancam terkatung-katung di laut lepas, seseorang yang mencoba membunuh Daeng Andipati, serta kasus yang membuat Gurutta dipenjara di sel kapal Blitar Holland. 
Tere Liye, dalam novel ini, sekaligus menyinggung beberapa isu, diantaranya seputar toleransi beragama. Dikisahkan dalam perjalanan dari Kolombo menuju Jeddah, para kelasi mengadakan perayaan Natal. Sebagaimana yang terjadi di masyarakat tentang polemik Natal bersama dan mengucapkan selamat Natal. Dalam sebuah dialog antara Daeng Andipati dengan Anna, Tere Liye menegaskan makna toleransi dari sudut pandang yang lain.

“...tanpa menghadiri acara itu, kita tetap menghormati mereka dengan baik, sama seperti Kapten Philips yang sangat menghormati agama kita. Pun tanpa harus mengucapkan selamat, kita tetap bisa saling menghargai. Tanpa perlu mencampur adukkan hal-hal yang sangat prinsipil di dalamnya (Liye, 2015: 499).

Di bagian yang lain, Tere Liye juga mengkritisi tentang kisah-kisah takhayul serta beragam pemberitaan hoax yang berceceran di media-media. Di mana diantara kaum Muslimin menelan mentah-mentah berita seputar bayi lahir dengan Al-Quran kecil, bayi lahir bisa bicara, ada asma Allah di awan, dan lain-lain sehingga mereka lupa bahwa mukjizat paling besar ada di rumah mereka. Diletakkan di lemari, di meja, dibiarkan berdebu tanpa pernah dibaca.

Ahmad Karaeng atau yang juga dikenal dengan sebutan Gurutta merupakan tokoh utama dan tokoh protagonis dalam novel "Rindu". Ahmad Karaeng adalah tokoh yang paling dihormati dan bijak dalam pelayaran kapal Blitar Holland. Ahmad Karaeng adalah ulama masyhur dari Makassar yang sering disapa Gurutta. Gurutta pintar berbahasa Belanda dan telah melakukan perjalanan ke berbagai daerah untuk menuntu ilmu. Gurutta Ahmad Karaeng adalah ulama yang menjawab pertanyaan-pertanyaan besar dari penumpang kapal Blitar Holland.

Di masa muda, Gurutta pernah belajar agama di Aceh. Lantas melanjutkan hingga ke Yaman dan Damaskus, mengkaji agama dari ahli tafsir dan pakar hadis terkemuka. la juga pernah menetap di Eropa dua tahun lamanya. Usia empat puluh lima barulah Gurutta kembali ke Makassar, menjadi imam Masjid Katangka.

Berdasarkan analisis psikologi sastra, berikut ini dideskripsikan perwatakan dari tokoh Ahmad Karaeng dalam novel Rindu karya Tere Liye.

\section{(a) Menerima Takdir}

Ahmad Karaeng memiliki watak yang cenderung menerima takdir. Hal ini dapat diindikasikan dari beberapa kutipan pada novel sebagai berikut. Gurutta berpesan kepada Bonda Upe yang mempunyai masa lalu yang kelam, yakni menjadi seorang cabo (pelacur) agar tidak lari dari kenyataan, menerima takdir masa lalunya dengan ikhlas karena masa lalu tidak akan bisa berubah. Dengan menerima masa lalu, maka kehidupan yang baru akan lebih bahagia. "Bagian yang pertama, kita keliru sekali jika lari dari kenyataan hidup, Nak. Aku tahu, lima belas tahun menjadi pelacur adalah nista yang tak terbayangkan. Tapi sungguh, kalau kau berusaha lari dari kenyataan itu, kau hanya menyulitkan diri sendiri. Ketahuilah, semakin keras kau berusaha lari, maka semakin kuat cengkeramannya. Semakin kencang kau berteriak melawan, maka semakin kencang pula gemanya memantul, memantul, dan memantul lagi memenuhi kepala (Liye, 2015: 312). Perwatakan Ahmad Karaeng yang cenderung menerima takdir masa lalu juga diberikan kepada Daeng Andipati yang sangat membenci ayahnya yang sudah meninggal karena perilaku buruk ayahnya kepada ibu dan keluarga Daeng Andipati. Menerima takdir sebagaimana ibu Daeng Andipati yang menerima takdir dengan tidak menyesali menikah dengan ayah Daeng Andipati. Pesan Ahmad Karaeng 
kepada bebrapa tokoh dalam novel Rindu menjelaskan bahwa seorang manusia tidak boleh hanya pasrah kepada takdir, tidak boleh menyesali apa yang telah terjadi. Menerima takdir dengan ikhlas maka akan dapat menghadapi masa depan dengan kebahagiaan.

\section{(b) Pribadi yang Selalu Bersyukur}

Ahmad Karaeng juga memiliki watak sebagai pribadi yang selalu bersyukur. Hal ini dapat dilihat dari beberapa kutipan dalam novel sebagai berikut. Dialog Ahmad Karaeng dengan Ambo Uleng berisi tentang bersyukur kepada Allah, SWT. sekecil apapun nikmat yang dirasakan. Ahmad Karaeng tersenyum demi mendengar pertanyaan itu, "Tentu saja, Ambo. Setiap hari aku jatuh cinta. Setidaknya setiap melihat matahari terbit, aku jatuh cinta, mensyukuri hidupku. Setiap menatap matahari tenggelam, aku jatuh cinta, berterima kasih atas sepanjang hari, baik itu menyebalkan ataupun menyenangkan. Bahkan melihat makanan dingin ini pun aku jatuh cinta" (Liye, 2015: 401).

Ahmad Karaeng memberikan pesan kepada Ruben agar bersyukur atas nikmat yang dirasakan sekarang dan tidak membayangkan sesuatu yang tidak terjadi. Ahmad Karaeng menatap kelasi dihadapannya, "Kau tidak perlu membayangkan sesuatu yang tidak terjadi, Ruben. Buat apa? Bahkan Ambo uleng baik-baik saja sekarang. Hidup ini akan rumit sekali jika kita sibuk membahas hal yang seandainya begini, seandainya begitu" (Liye, 2015: 331).

\section{(c) Menaati Perintah Allah, SWT.}

Ahmad Karaeng berpesan kepada Mbah Kakung Slamet untuk menaati perintah Allah, SWT., seperti shalat karena shalat merupakan penolong terbaik ketika membutuhkan pertolongan. Dialog yang dilakukan Ahmad Karaeng kepada Mbah Kakung Slamet tentang kematian Mbah Putri ketika sedang Shalat menunujukkan perilaku menaati perintah Allah, SWT. "Dalam Alquran, ditulis dengan indah, minta tolonglah kepada sabar dan shalat. Kita disuruh melakukan itu, Kang Mas. Bagaimana mungkin sabar bisa menolong kita? Tentu saja bisa. Dalam situasi tertentu, sabar bahkan adalah penolong paling dahsyat. Tiada terkira. Dan shalat, itu juga penolong terbaik tiada tara. Aku senang mendengar kabar, meski Kang Mas menolak makan, tapi masih mau shalat tepat waktu. Itu berarti Kang Mas masih memiliki harapan, doa-doa. Sungguh beruntung orang-orang yang sabar dan senantiasa menegakkan shalat." (Liye, 2015: 472).

Dialog yang dilakukan Ahmad Karaeng dengan Ambo Uleng memberikan pesan untuk menaati perintah Allah, SWT., yakni tidak melakukan maksiat dan tidak melakukan hal-hal yang melanggar peraturan agama. "Dengan meyakini itu, maka tidak mengapa kalau kau patah hati, tidak mengapa kalau kau kecewa, atau menangis tergugu karena harapan, keinginan memiliki tapi jangan berlebihan. Jangan merusak diri sendiri. Selalu pahami, cinta yang baik selalu mengajari kau agar menjaga diri. Tidak melanggar batas, tidak melewati kaidah agama. Karena esok lusa, ada orang yang mengaku cinta, tapi dia melakukan begitu banyak maksiat, menginjak-injak semua peraturan dalam agama, menodai cinta itu sendiri ...." (Liye, 2015: 493). Ketika sedang mengalami cobaan, maka solusinya adalah menjalankan perintah Allah, SWT. dan menjauhi segala larangannya dengan cara berdo'a dan berserah diri kepada Allah, SWT. 


\section{(d) Tobat}

Dialog Ahmad Karaeng kepada Ambo Uleng adalah mengenai tobatnya Ambo Uleng yang mulai belajar agama. "Jika harapan dan keinginan memiliki itu belum tergapai, belum terwujud, maka teruslah memperbaiki diri sendiri, sibukkan dengan belajar. Kau sudah melakukannya sejak terjebak di ruangan kecil antara hidup dan mati. Kau mulai belajar ilmu agama. Kau juga belajar tentang kapal uap ini. Dan kelebihan kau yang paling utama adalah kau senantiasa berbuat baik kepada siapa pun. Maka teruslah menjadi orang baik seperti itu. Insya Allah, besok lusa, Allah sendiri yang akan menyingkapkan misteri takdirnya" (Liye, 2015: 493). Tobat adalah melepaskan diri dari segala dosa dan maksiat, menyesali dosa-dosa yang telah diperbuat, dan bertekad untuk tidak mengulangi lagi di sisa-sisa umurnya. Hati yang dipenuhi dengan cinta dan ketakwaan kepada Tuhan tidak akan dirasuki kelalaian, hanya orang-orang yang mengabaikan perintah dan bimbingan-Nya yang akan berada dalam kesesatan.

\section{(e) Tawakal}

Ahmad Karaeng memberikan pesan kepada Mbah Kakung Slamet agar menyerahkan segala urusan kepada Allah, SWT. "Yang kedua, biarkan waktu mengobati seluruh kesedihan, Kang Mas. Ketika kita tidak tahu mau melakukan apalagi, ketika kita merasa semua sudah hilang, musnah, habis sudah, maka itulah saatnya untuk membiarkan waktu menjadi obat terbaik. Hari demi hari akan menghapus selembar demi lembar kesedihan. Minggu demi minggu akan melepas sepapan demi sepapan kegelisahan. Bulan, tahun, maka rontok sudahlah bangunan kesedihan di dalam hati. Biarkan waktu mengobatinya, maka semoga kita lapang hati menerimanya. Sambil terus mengisi hari-hari dengan baik dan positif" (Liye, 2015: 472).

Pesan Ahmad Karaeng kepada Mbah Kakung untuk menyerahkan semua urusan kepada Allah, SWT., lapang hati menerima takdir dan senantiasa berikhtiar dengan melakukan kegiatan yang positif. Orang yang menyerahkan segala sesuatunya kepada Allah, SWT. maka orang tersebut tidak akan takut menghadapi masa depan, hatinya merasa tenang dan tentram karena yakin Allah, SWT. pasti akan memberikan keadilan, rahmat-Nya kepada orang yang memiliki sikap tawakal.

\section{(f) Adil terhadap Diri Sendiri}

Pesan Ahmad Karaeng kepada Ambo Uleng untuk menjaga dan merawat dirinya agar menjauhi hal-hal yang dilarang agama yang dapat merusak diri sendiri. "Maka jangan pernah merusak diri sendiri. Kita boleh jadi benci atas kehidupan ini. Boleh kecewa. Boleh marah. Tapi ingatlah nasihat lama, tidak pernah ada pelaut yang merusak kapalnya sendiri. Akan dia rawat kapalnya, hingga dia bisa tiba di pelabuhan terakhir. Maka, jangan rusak kapal kehidupan milik kau, Ambo, hingga dia tiba di dermaga terakhirnya" (Liye, 2015: 284). "Dengan meyakini itu, maka tidak mengapa kalau kau patah hati, tidak mengapa kalau kau kecewa, atau menangis tergugu karena harapan, keinginan memiliki tapi jangan berlebihan. Jangan merusak diri sendiri. Selalu pahami, cinta yang baik selalu mengajari kau agar menjaga diri. Tidak melanggar batas, tidak melewati kaidah agama. Karena esok lusa, ada orang yang mengaku cinta, tapi dia melakukan begitu banyak maksiat, menginjak-injak semua peraturan dalam agama, menodai cinta itu sendiri .... (Liye, 2015: 493). Keadilan pertama kali harus ditunjukkan terhadap diri sendiri. Orang yang atas dirinya saja tidak adil maka ia sulit akan diharapkan berbuat adil terhadap orang lain. Pesan yang diberikan Ahmad Karaeng kepada beberapa tokoh dalam novel "Rindu" sesuai dengan penjelasan tentang keadilan 
terhadap diri sendiri, yakni jangan sampai merusak diri sendiri atas takdir yang tidak sesuai dengan harapan.

Selain itu, juga terdapat beberapa perwatakan tokoh Ahmad Karaeng yang lain, seperti: (a) Gigih; gigih ditunjukkan dalam dialog Ahmad Karaeng kepada Bonda Upe dimana suami Bonda Upe pantang menyerah menghadapi kenyataan masa lalu istrinya yang pahit dan selalu menyemangati istrinya. (b) Tidak Mementingkan Diri Sendiri; Ahmad Karaeng memberikan pesan kepada Daeng Andipati agar tidak memaksakan kehendaknya kepada Ambo Uleng. (c) Sabar: Ahmad Karaeng memberikan pesan kepada jama'ah majelis ilmu agar senantiasa bersabar dalam segala urusan. (d) Ikhlas: ikhlas merupakan salah satu pesan yang diberikan Ahmad Karaeng kepada Mbah Kakung Slamet. Ikhlas menerima takdir bahwa kematian Mbah Putri Slamet di dalam kapal dan cara pemakamannya dengan ditenggelamkan ke dasar laut. (e) Tegar; Ahmad Karaeng memberikan pesan kepada Bonda Upe agar tegar menghadapi masalah, tidak menanggapi penilaian orang lain yang akan menjatuhkan diri sendiri tentang siapa sebenarnya diri kita apakah baik atau buruk. (f) Optimis: optimis adalah salah watak Ahmad Karaeng, seperti saat Ahmad Karaeng menyampaikan pesan kepada Ambo Uleng yang berputus asa menjalani hidupnya. Ambo Uleng tidak mempunyai semangat untuk hidup. (g) Lapang Dada: Ahmad Karaeng merupakan pribadi yang lapang dada. Hal ini dapat dilihat saat Ahmad Karaeng berpesan kepada Daeng Andipati untuk berlapang dada dalam memaafkan kesalahan ayahnya yang sudah meninggal di masa lampau. (h) Ta'awun: pesan Ahmad Karaeng kepada Ambo Uleng adalah untuk selalu menolong orang lain (ta'awun) karena Allah, SWT. akan menolong seseorang yang mau menolong saudaranya. (i) Berkumpul dengan Orang Baik: Ahmad Karaeng berpesan kepada Bonda Upe yang selalu menyendiri karena takut masa lalunya diketahui agar mau berkumpul dengan orang lain. (j) Solidaritas; pesan Ahmad Karaeng kepada jamaah haji di Kapal adalah menjunjung tinggi solidaritas atau persaudaraan sesama muslim. (k) Menghargai orang lain; Ahmad Karaeng mengingatkan Daeng Andipati agar tidak menghina Ambo Uleng yang meminta belajar shalat kepada Gurutta. Pesan yang disampaikan Ahmad Karaeng kepada Daeng Andipati adalah untuk menghargai orang lain. (I) Pemaaf; dialog yang dilakukan Ahmad Karaeng kepada Daeng Andipati adalah cerminan tentang watak Ahmad Karaeng sebagai orang yang pemaaf. Orang yang memaafkan adalah orang yang mempunyai jiwa yang besar.

Konflik batin adalah konflik yang dialami oleh seseorang dalam hati, jiwa seorang tokoh cerita yang merupakan permasalahan yang terjadi akibat adanya pertentangan antara dua keinginan, keyakinan, pilihan yang berbeda, harapan dan masalah. Jadi, konflik batin adalah pergolakan yang terjadi dalam batin manusia, membuat pertentangan antara dua pilihan sehingga dapat mempengaruhi perilaku manusia itu sendiri.

Ahmad Karaeng merupakan salah seorang ulama masyur di zaman itu. Ahmad Karaeng atau juga dikenal dengan sebutan Gurutta masih terbilang keturunan raja Gowa pertama yang memeluk Islam, Sultan Alauddin. Dalam darahnya mengalir darah raja paling terkenal di Sulawesi, Sultan Hasanuddin yang cucu Sultan Alauddin. Gurutta juga masih kerabat dari Syekh Yusuf, ulama besar yang dibuang Belanda ke Sri Lanka, kemudian dibuang lagi ke Cape Town, Afrika Selatan, tiga ratus tahun lalu.

Ahmad Karaeng tiba-tiba kehilangan keyakinan atas apa yang akan ia tumpahkan-begitu saja. Dijeda shalat Maghrib, disela shalat Isya, tetap saja hasilnya 
sama. Lembaran-lembaran kertas itu tetap kosong. Lantas pertanyaan-pertanyaan itu mengungkung kepalanya. Berikut kutipannya.

Apakah mungkin karena ia sendiri memang tidak pernah seyakin itu atas pengetahuan yang ia miliki? Apakah mungkin karena ia sendiri memang tidak sebijak, setangguh bahkan sebaik itu? Mungkin ialah bagian paling munafik dalam seluruh cerita. Bagaimana ia menulis sebuah buku yang membuat jutaan pembaca tergerak hatinya, jika ia sendiri tidak tergerak? Bagaimana ia bicara tentang perlawanan, tapi ia sendiri adalah pelaku paling pengecut (Liye, 2015: 232).

Berdasarkan kutipan tersebut Ahmad Karaeng merasa bahwa dirinya adalah seorang yang munafik, ia dapat bersikap bijak di depan siapa pun namun hati dan pikirannya selalu menanyakan apakah ia setangguh kata-kata yang diucapkannya. la menyimpan persaan bersalah dan menganggap dirinya sebagai pengecut. Konflik lain yang dialami oleh Ahmad Karaeng sebagai berikut: "Dalam semalam, aku kehilangan dua orang paling kusayangi. Guruku, Syekh Raniri, dan calon istriku Cut Keumala. Hidupku yang sebenarnya begitu indah, dalam semalam, langsung menghujam ke dasar bumi. Seluruh kesedihan menyerapku." (Liye, 2015: 405).

Berdasarkan kutipan tersebut, Ahmad Karaeng sangat terpukul dengan masa lalu yang telah ia lewati. la sangat sedih telah kehilangan orang-orang yang sangat dicintai dan dihormatinya dalam semalam. Pada saat kejadian Belanda menyerang komplek pesantren Syekh Raniri, ia terluka parah dan dilarikan dan disembunyikan di rumah-rumah warga terdekat. Penyesalan terbesar Ahmad Karaeng pada kejadian itu adalah tidak dapat menyelamatkan orang-orang yang dekat padanya. Penyesalan itu sampai sekarang dialaminya.

\section{Kesimpulan}

Berdasarkan hasil analisis data dalam novel Rindu Karya Tere Liye dengan menggunakan pendekatan psikologi sastra diperoleh simpulan-simpulan sebagai berikut. (1) Perwatakan tokoh Ahmad Karaeng dalam novel Rindu karya Tere Liye meliputi: (a) menerima takdir, (b) pribadi yang selalu bersyukur, (c) menaati perintah Allah, SWT., (d) tobat, (e) tawakal, (f) adil terhadap diri sendiri, (g) gigih, (h) tidak mementingkan diri sendiri, (i) sabar, (j) ikhlas, (k) tegar, (I) optimis, (m) lapang dada, (n) ta'awun (selalu menolong orang lain), (o) berkumpul dengan orang baik, $(p)$ memiliki solidaritas, (r) menghargai orang lain, dan (s) pemaaf. (2) Konflik batin pada tokoh Ahmad Karaeng dalam novel Rindu karya Tere Liye merupakan konflik internal. Konflik internal, yaitu konflik batin atau kejiwaan. Konflik batin yang dialami Ahmad Karaeng adalah adanya perasaan pada Ahmad Karaeng bahwa dirinya adalah seorang yang munafik, ia dapat bersikap bijak di depan siapa pun namun hati dan pikirannya selalu menanyakan apakah ia setangguh kata-kata yang diucapkannya. la menyimpan persaan bersalah dan mengaggap dirinya sebagai pengecut. Ahmad Karaeng sangat terpukul dengan masa lalu yang telah ia lewati. la sangat sedih telah kehilangan orangorang yang sangat dicintai dan dihormatinya dalam semalam. Pada saat kejadian Belanda menyerang komplek pesantren Syekh Raniri, ia terluka parah dan dilarikan dan disembunyikan di rumah-rumah warga terdekat. Penyesalan terbesar Ahmad Karaeng pada kejadian itu adalah tidak dapat menyelamatkan orang-orang yang dekat padanya. Penyesalan itu sampai sekarang ia alami. 
Berdasarkan hasil analisis konflik batin dan perwatakan tokoh Ahmad Karaeng dalam novel Rindu karya Tere Liye yang dilakukan dengan pendekatan psikologi sastra, peneliti menyarankan sebagai berikut. (1) Bagi guru Bahasa Indonesia: (a) Hasil penelitian dalam novel Rindu karya Tere Liye, dapat diimplementasikan dari beberapa kategori. (1) kesesuaian novel dengan siswa: a) Fungsi Sastra, b) tahap-tahap perkembangan siswa, c) fungsi pembelajaran sastra. (2) Kesesuaian hasil penelitian dengan SKKD: a) Kriteria penyusunan bahan pengajaran sastra, b) Bahan ajar, c) Standar Kompetensi dan Kompetensi Dasar. (3) Hasil penelitian sebagai bahan ajar: a) Bahan ajar yang berupa novel, b) Bahan ajar yang berisi sinopsis, c) Bahan ajar yang berupa analisis struktur, d) Bahan ajar yang berupa nilai moral. (b) Dalam pembelajaran bahasa dan sastra Indonesia mengenai menganalisis teks novel dibelajarkan pada peserta didik tingkat SMA kelas XII. Novel dapat dianalisis secara intrinsik dan ekstrinsik. Salah satu unsur ekstrinsik dalam novel ialah mengenai psikologi khususnya kepribadian tokoh dapat menggunakan psikologi dalam novel Rindu karya Tere Liye karena dalam novel tersebut terdapat tiga psikologi khususnya kepribadian tokoh, yaitu id, ego, dan superego. (c) Novel Rindu karya Tere Liye dapat digunakan sebagai bahan ajar dalam pembelajaran sastra untuk meningkatkan kepekaan peserta didik dalam menganalisis dan mengapresiasi teks novel baik secara lisan dan tulisan. (d) Pada pembelajaran menganalisis psikologi, khususnya kepribadian tokoh dalam novel Rindu karya Tere Liye, pendidik pada mata pelajaran bahasa Indonesia hendaknya menugaskan peserta didik untuk membaca keseluruhan novel bukan kutipan novel. Tujuannya agar peserta didik dapat memahami isi novel dengan baik dan dapat mengambil hal positif yang berkaitan dengan aspek psikologi khususnya kepribadian untuk diimplikasikan ke dalam kehidupan sehari-hari sebagai sarana pembentuk tingkah laku.

(2) Bagi para penulis sastra khususnya penulis prosa rekaan berbentuk novel melalui kreasi imajinasinya agar senantiasa menyadari betapa pentingnya kehadiran konflik dalam membangun sebuah cerita (tanpa mengabaikan unsur-unsur intrinsik lainnya), sehingga karya yang diciptakan lebih hidup dan menarik perhatian dan waktu pembaca untuk menyelesaikan bacaanya dan menemukan pesan yang terkandum di dalamnya. (3) Bagi para peneliti selanjutnya yang akan mengambil judul yang relevan, agar mereka melanjutkan penelitian ini dengan tidak memisahkan konflik dengan unsur intrinsik lainnya dalam sebuah karya sastra, khususnya novel. Hal ini di lakukan agar penelitian dapat dilakukan secara menyeluruh dan berkeseimbangan tanpa mementingkan unsur intrinsik tertentu.

\section{Daftar Pustaka}

Kartika, D. A. (2008). Konflik Batin Tokoh Utama dalam Novel 'Nayla' Karya Djenar Maesa Ayu: Tinjauan Psikologi Sastra. Skripsi. Tidak Dipublikasikan. Surakarta: Universitas Muhammadiyah Surakarta.

Kesuma, T. J. (2007). Pengantar (Metode) Penelitian Bahasa. Yogyakarta: Carasvati Books.

Minderop, A. (2013). Psikologi Sastra: Karya Sastra, Metode, Teori, dan Contoh Kasus. Jakarta: Yayasan Pustaka Obor Indonesia. 
Pradopo, R. D. (2007). Pengkajian Fiksi. Yogyakarta: Gadjah Mada University Press.

Ratna, N. K. (2011). Teori, Metode, dan Teknik Penelitian Sastra. Yogyakarta: Pustaka Pelajar.

Sayuti, S. A. (2010). Berkenalan dengan Peosa Fiksi. Yogyakarta: Gama Media.

Stanton, R.. (2012). Teori Fiksi. Yogyakarta: Pustaka Pelajar.

Sugiyono. (2014). Metode Penelitian Pendekatan Kuantitatif, Kualitatif, R \& D. Bandung: Alfabeta.

Sutopo, H.B. (2002). Metodologi Penelitian Kualitatif (Dasar Teori dan Terapannya dalam Penelitian). Surakarta: Sebelas Maret University Press.

Tarigan, H. G. (2008). Prinsip-prinsip Dasar Sastra. Bandung: Angkasa.

Walgito, B. (2010). Pengantar Psikologi Umum. Yogyakarta: Yayasan Penerbitan Fakultas Psikologi UGM.

Wiyatmi. (2011). Pengantar Psikologi Sastra. Yogyakarta: Kanwa Publisher. 